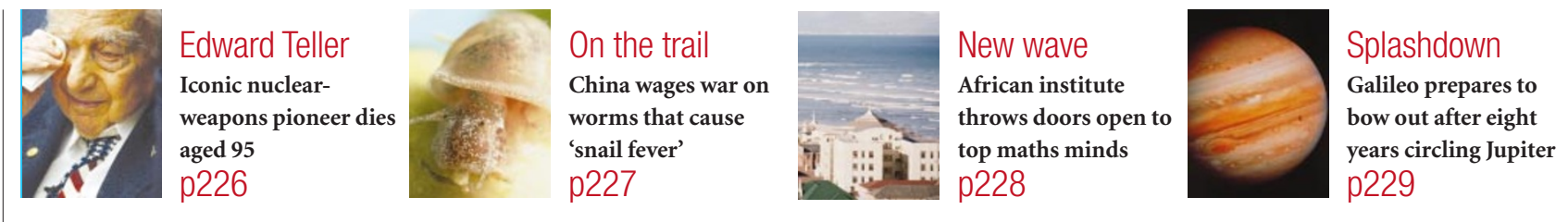

\title{
Drug companies snub antibiotics as pipeline threatens to run dry
}

Tom Clarke, Chicago

Major drug companies are pulling out of antibiotic development - and their timing couldn't be worse, a leading meeting on infectious disease was told this week.

Speakers at the 43rd Interscience Conference on Antimicrobial Agents and Chemotherapy in Chicago said that many firms, such as Roche and Eli Lilly, are turning away from antibiotics to concentrate on treatments for chronic illness instead.

Yet the need for new drugs has never been greater. Resistance to antibiotics is growing - $20 \%$ of infections in US hospitals involve multidrug-resistant bacteria, reports the Food and Drug Administration (FDA). Moreover, the pipeline of new antibiotics is running dry: the FDA has approved just two this year.

"There's unequivocal evidence that antimicrobial research is on a steep downward slope," said John Edwards, head of policy at the Infectious Diseases Society of America. Recent scares over diseases such as anthrax have served as a reminder that it is impossible to predict when new antiinfectious agents will be needed.

The retreat was palpable at the meeting. There were $10 \%$ fewer presentations of new

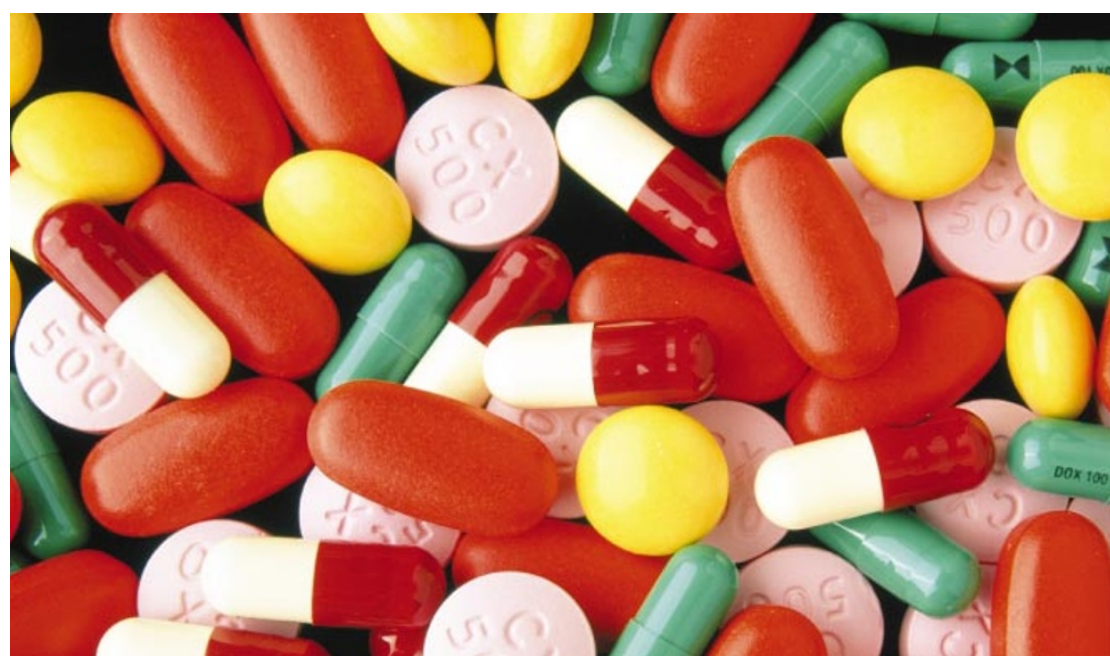

Pick'n' mix: despite the variety of existing antibiotics, more options are needed as drug resistance mounts.

drug candidates than last year, and a slump in attendees from industry. "Attendance is down, the number of new antimicrobial agents is down," said Barbara Murray of the University of Texas Medical School in Houston, chair of the meeting's programme committee.

Big drug companies are in the financial doldrums, and antibiotics research is easy to

\section{Europe offers grants to young stars}

\section{Jim Giles, London}

Young researchers are being offered the chance to control their own five-year budgets of more than 1 million (US $\$ 1$ million), under a scheme unveiled this week by European research agencies.

The European Young Investigators awards are aimed at enticing the world's best young scientists to stay in Europe, or move there to work. Researchers from any country who have between two and ten years' postdoctoral experience can apply. Those confident of fulfilling the criteria - they must have the "potential to become a worldclass leader" in their field - stand to receive a 150,000-250,000 a year for five years.
The scheme is the brainchild of the European Heads of Research Councils, a body that unites the funding organizations of 15 countries. Potential applicants must first find a research institution in one of the participating countries to back their proposal. These are then vetted by the host nation's research council, before the European Science Foundation an umbrella group of European science organizations - picks the 25 winners.

Researchers from the physical, medical, biological and social sciences are invited to apply by 15 December, and the winners will be announced next September. www.esf.org cut, said Steven Projan, who directs such work at Wyeth's facility in Pearl River, New York. Natural selection makes resistance inevitable, rendering any antibiotic less profitable over time. New drugs that combat resistant bacteria are often held in reserve by doctors to treat only the most stubborn infections - so they aren't big earners. And unlike drugs for chronic illnesses such as heart disease, antibiotics cure people, eliminating their customers.

The shift away from infectious diseases could have lasting effects on antibiotic research in academia, warned microbiologist Stuart Levy of Tufts University School of Medicine in Boston, Massachusetts. Jobs for microbiologists in the drug industry are becoming rarer, he said, as is industry funding for basic microbiology.

Levy suggested that antibiotics be subjected to lighter regulation and given more public-research funds, to reflect the fact that infectious diseases place a burden on society. "These are societal drugs," he argued.

But Martin Sprinkslee, vice-president of product development with Bayer in West Haven, Connecticut, admitted that the industry's pleas for special treatment may receive little sympathy."There is a perception that the industry has made unethically high returns on sales in the past," he said. 